\title{
Landscape monitoring of post-industrial areas using LiDAR and GIS technology
}

\author{
Piotr Wężyk ${ }^{1}$, Marta Szostak ${ }^{1}$, Wojciech Krzaklewski², Marek Pająk ${ }^{2}$, \\ Marcin Pierzchalski ${ }^{3}$, Piotr Szwed ${ }^{3}$, Pawel Hawryło ${ }^{1}$, Michał Ratajczak ${ }^{1}$ \\ ${ }^{1}$ University of Agriculture in Krakow, Faculty of Forestry \\ Institute of Forest Resources Management \\ Department of Forest Management \\ Geomatics and Forest Economics - Laboratory of Geomatics \\ Aleja 29 Listopada 46, 31-425 Krakow, Poland \\ e-mail: p.wezyk@ur.krakow.pl; m.szostak@ur.krakow.pl; p.hawrylo@ur.krakow.pl; gorhydrus@gmail.com
}

\author{
${ }^{2}$ University of Agriculture in Krakow \\ Faculty of Forestry \\ Institute of Forest Ecology and Silviculture \\ Department of Forest Ecology and Reclamation \\ Aleja 29 Listopada 46, 31-425 Kraków, Poland \\ e-mail: wkrzak@ar.krakow.pl; rlpajak@cyf-kr.edu.pl \\ ${ }^{3}$ ProGea Consulting Krakow \\ 9 Henryka Pachońskiego St., 31-223 Krakow, Poland \\ e-mail: marcin.pierzchalski@progea.pl; piotr.szwed@progea.pl
}

Received: 16 October 2014 / Accepted: 23 December 2014

\begin{abstract}
The quarrying industry is changing the local landscape, forming deep open pits and spoil heaps in close proximity to them, especially lignite mines. The impact can include toxic soil material (low $\mathrm{pH}$, heavy metals, oxidations etc.) which is the basis for further reclamation and afforestation. Forests that stand on spoil heaps have very different growth conditions because of the relief (slope, aspect, wind and rainfall shadows, supply of solar energy, etc.) and type of soil that is deposited. Airborne laser scanning (ALS) technology deliver point clouds (XYZ) and derivatives as raster height models (DTM, $\mathrm{DSM}, \mathrm{nDSM}=\mathrm{CHM}$ ) which allow the reception of selected $2 \mathrm{D}$ and $3 \mathrm{D}$ forest parameters (e.g. height, base of the crown, cover, density, volume, biomass, etc). The automation of ALS point cloud processing and integrating the results into GIS helps forest managers to take appropriate decisions on silvicultural treatments in areas with failed plantations (toxic soil, droughts on south-facing slopes; landslides, etc.) or as regular maintenance. The ISOK country-wide project ongoing in Poland will soon deliver ALS point cloud data which can be successfully used for the monitoring and management of many thousands of hectares of destroyed post-industrial areas which according to the law, have to be afforested and transferred back to the State Forest.
\end{abstract}

Keywords: ALS, vegetation parameters, post- lignite mining areas, reclamation 


\section{Introduction}

The industrial development of countries with mineral resources, often leads to strong local transformations and changes in the landscape, water bodies, climate, or even to disturbances of biodiversity. The quarrying industry frequently leaves behind hard coal or lignite mines, such as open pits and spoil heaps, open pit quarries (stones, sand) and open pit sulfur mine spoils as well. In Poland, in 2012 about 64343 hectares $(0.2 \%$ of the country's area) have been devastated and degraded and approximately 2.720 ha of these sites were reclaimed (Dmochowska and Witkowski, 2013). In the 1970's and 80 's, every year, approx. 4.400 ha was reclaimed when in the year 2000 only 2.200 ha. Following the technical definition, land reclamation consists of its restoration or assigning a utility or natural value. Devastated or degraded land is restored through appropriate landscaping, improving physical and chemical properties, regulating waterways, regenerating soils, strengthening scarps as well as constructing or reconstructing a necessary road system. From an ecological point of view, reclamation is a process of restoring the full functionality and complicity of the ecosystem (Pietrzykowski and Krzaklewski, 2007).

The management and monitoring of the natural environment, including areas degraded by mining activities is connected with the constant need for very precise data, both geometric (vectors of the object borders, terrain models, the relative elevation of the objects etc.) as well as attributes (descriptive) information. In the case of woody vegetation, there is a whole range of features used in the forest inventory (e.g. height, canopy density, species composition, tree stand density) for the assessment of the development phase or the condition of forest stands. Apart from traditional forest inventory fieldwork, a massive use of geospatial technology is noticeable, including digital airborne photographs/orthophotomaps (RGB or CIR; 3D/2D), precise measurements using GNSS (Szostak and Wezyk, 2013; Wezyk and Krzaklewski, 1999), UAV imagery, remote sensing satellite images (Drzewiecki et al. 2014; Hejmanowska, 2006), or Light Detection and Ranging (LiDAR) technology (Szostak et al., 2014; Wezyk, 2012; Wezyk et al., 2013). LiDAR is acronym for Airborne Laser Scanning (ALS), Terrestrial Laser Scanning (TLS) or Mobile Laser Scanning or Satellite Laser Scanning (SLS). The data sets collected with the mentioned technologies are integrated into Geographic Information Systems (GIS) and used for generation of new 2D and 3D spatial information.

The basic task connected with ALS data processing for vegetated areas (forest, trees, other woodlands etc.), is the filtration of impulses reflected from the layer of trees, and from those reflecting from the ground (Hyyppä et al., 2005). The applied algorithms for modeling DTM (Digital Terrain Model), based on the class of points (ground=2), was earlier selected from the whole dataset (Kraus and Pfeifer, 1998). In this process, the most often used algorithm is that of the active TIN model (Axelsson, 2000). The TIN model in the following step of the analyses is transformed into a raster model GRID (ESRI) or GeoTIFF (Wezyk et al., 2008). After selecting the point cloud ALS of the class ,ground”, the representations of other classes based on 
the relative height above the ground, e.g.: low vegetation (height range: $0.0-0.4 \mathrm{~m}$ ), medium $(0.041-2.0 \mathrm{~m})$ or high $(>2.01 \mathrm{~m})$. The class of buildings and infrastructure („buildings”) was generated automatically due to the detection of planar surfaces (roofs) in TerraScan (Terrasolid_software).

The application of ALS technology in environmental management, apart from the important DTM (deriving slope and aspect) leads to using models such as: the normalized Digital Surface Model (nDSM). The nDSM denotes the surface representing the relative heights of objects, e.g. trees, buildings, and can be applied, among others, to mark the limits (e.g. height class) of the vegetation, supported by radiometric information from aerial imageries (Szostak et al., 2014). In case of forests, the advanced analyses (2D and 3D) of vegetation structure (Koch et al., 2006) based on the Crown Height Model (CHM) which means the same as nDSM generated from classes; ground + vegetation. Directly in the ALS point cloud some forest inventory parameters can be retrieved, such as: height (top of single tree, base of crown, or mean upper height of the whole stand), horizontal canopy density or light penetration index (2D), number of trees (e.g. ha ${ }^{-1}$ ), number and area of gaps (Wezyk et al., 2013), crown size (diameter, radius, area $2 \mathrm{D} / 3 \mathrm{D}$, volume) or vertical structure of the forest stand (Wezyk, 2008). Features strongly correlated with height, but impossible to be directly defined, include the trunk diameter (DBH) or biomass (Næsset, 1997). Counting the number of trees based on ALS data is directly connected with the delineation of individual tree crowns (Yu et al., 2004) the use of local maxima or GIS algorithms (e.g. the reversed catchment method; Wezyk et al., 2010). The Object Based Image Analysis (OBIA or GEOBIA) approach based on automatic segmentation and grouping of pixels according to the height attribute (nDSM) or standard deviation, but also the shape and other spectral characteristics, can be used to support the integration of ALS data with aerial or satellite imagery (Szostak et al., 2014).

The purpose of the presented work was an demonstration of the potential use of ALS point cloud data and some derivatives (raster height models: DTM, DSM, $\mathrm{nDSM}$ ) to demonstrate the semi-automatic process of retrieving selected $2 \mathrm{D}$ and $3 \mathrm{D}$ inventory parameters of the vegetation overgrowing the reclaimed spoil heaps of the lignite mines in Turow and Belchatow (Poland) and integration within GIS system helping to manage those newly created initial forest ecosystems.

\section{Test area, material and methods}

The study was performed on two spoil heaps (Figure 1) located in Turow (Bogatynia; SW Poland) and Belchatow (central Poland), who are remnants of the brown coal mining.

The Lignite Mine Turow (5056’39.56”N; 1458'20.05”E) lies in the Sudetic ecoclimatic zone, submontane macroregion. The period of vegetation is one of the longest in Poland (200-220 days), and the annual sum of precipitation ranges from 700 to $800 \mathrm{~mm}$. The area of the outer dump of the Lignite Mine Turow in Bogatynia 
is about 2.175 ha and is one of the biggest in the world. Recently, the dump was secured and the forest reclamation work was carried out. A significant part of the reclaimed area is already administered by the National Forest Holding "State Forests" (Forest District Piensk).

The spoil heap Belchatow (1.480 ha) is located in central part of Poland $\left(51^{\circ} 12^{\prime} 44.99^{\prime \prime} \mathrm{N} ; 1^{\circ} 25^{\prime} 47.28^{\prime \prime} \mathrm{E}\right)$. The climate in the Belchatow area is transitional and changeable due to frequent interactions between polar maritime and continental air masses. The average annual temperature is around $7.6-8^{\circ} \mathrm{C}$ and the total precipitation ranges from 550 to $600 \mathrm{~mm}$. The vegetation period lasts from 210 to 218 days. The external spoil heap ranges in height from 120 to $180 \mathrm{~m}$ and covers an area of $1.480 \mathrm{ha}$, where the area of slopes is 1200 ha. The Belchatow dump was constructed with a non-selective method in period 1977-1994. About 134 million $\mathrm{m}^{3}$ of overburden rocks covering the lignite deposit were dumped in total. The first forestations of the outer dump of the „Belchatow mine" started in 1984, mainly with poplar trees. The afforestations were started from the north to the east and from the west to the south. Looking at the composition of tree species on the spoil heap, one should differentiate between the top of the dump and its slopes, because in both cases the vegetation fulfills different tasks and was introduced in another way. Scotch pine, despite good growth indicators, were not grown on the slopes, but composes $50 \%$ of all species. The remaining tree species planted on top are birch (26\%), alder (12\%) and native species of oak $(9 \%)$. On the slopes, the most common species are e.g.: birch $24 \%$, black locust $16 \%$, alder $16 \%$, and pine $12 \%$.
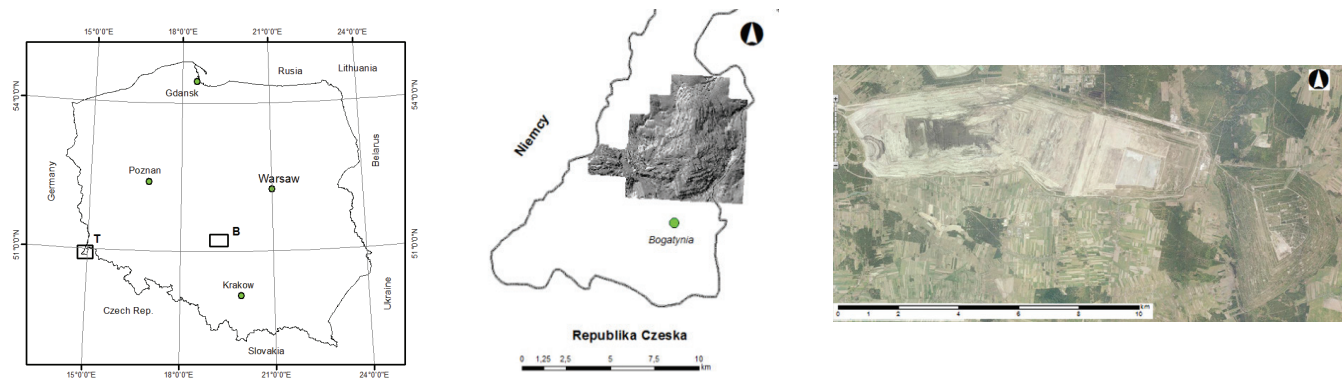

Fig. 1. The study areas on the map of Poland (left); the enlarged part of Turow (T) with the spoil heap (middle); and open pit with outer dump in Belchatow (B)

The ALS point cloud data used in the presented study came from the ISOK (Informatics System of the Country Protection from extraordinary threat) project which was run in Poland in 2011 with the goal of covering the whole country until 2016 (already approximately $70 \%$ is done). The ALS point clouds used had a density of $4 \mathrm{pts} / \mathrm{m}^{2}$. The classification was done according rules of APSRS (LAS format; ver. 1.2). The digital map of forest compartment on the outer dumps was made by the on-screen vectorization of the analogue maps and its calibration (PL-1992) and 
verification using nDSM (ArMap Esri). The TerraScan and TerraModeler (Terrasolid) modules were applied to perform: verification of ALS point clouds, classification, filtration, generating DTM, conversion of height models into GRID etc. To define the 2D and 3D parameters of vegetation FUSION (e.g. using cloudmetrics algorithm; McGaughey, 2012) and LASTools (Rapidlasso, 2014) software were used. For the GIS modelling and calculations of hillshade and some spatial analyses the ArcGIS ESRI (ver. 10.2) software was used.

\section{Results}

In this chapter, some selected examples of 2D and 3D parameters for forest vegetation growing in the Turow and Belchatow lignite mine areas, retrieved from ALS point cloud analyses and their derivates (raster models) will be presented.

\section{Digital Terrain Model (DTM)}

Based on ALS point cloud class ,ground", the DTM was generated (TIN transform to GRID; GSD 1.0 m, Figure 2), opening the possibility of the classification of relative heights of three vegetation classes and GIS aspect and slope analysis and hillshade relief of DTM as well. The last model is very useful for checking erosion risk and searching for local landslides. Using DTM surface, the volume of the spoil heap was calculated, reaching for Turow 1.43 milliard $\mathrm{m}^{3}$ and Belchatow 1.36 milliard $\mathrm{m}^{3}$. The relative height of Turow was $246.9 \mathrm{~m}$ (from lowest part in W $223.26 \mathrm{~m}$ a.s.1.; max.: $470.16 \mathrm{~m}$ a.s.1.) and $212.4 \mathrm{~m}$ in case of Belchatow (lowest $\mathrm{W}$ part $19.15 \mathrm{~m}$ a.s.1.; max.: $405.5 \mathrm{~m}$ a.s.1.)
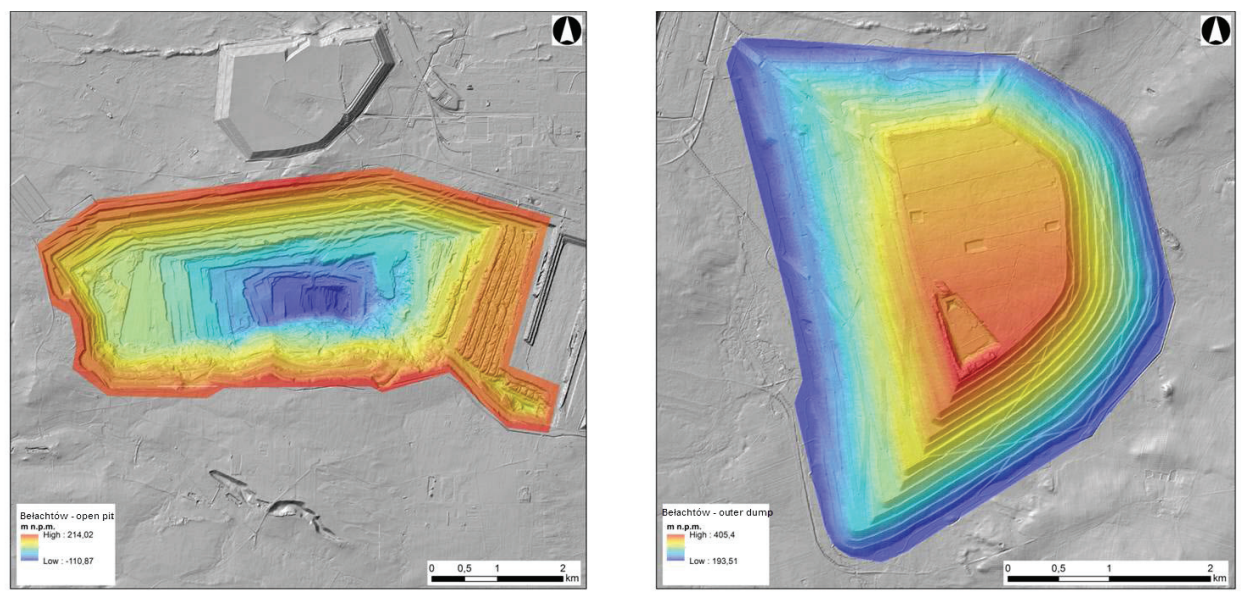

Fig. 2. DTM - open pit (left) and outer dump (right) in Belchatow 
The control based on precise DTM confirmed that most slopes of the Belchatow outer dump meet the requirements from the reclamation project (optimal slopes values $1: 3.5)$. The areas of the slopes exceeding the $15^{\circ}$ cover only $14 \%$ the area. Remaining areas covers: $0^{\circ}$ to $2.5^{\circ}(32 \%) ; 2.5^{\circ}-5^{\circ}(13 \%) ; 5^{\circ}-10^{\circ}(18 \%)$ and $10^{\circ}-15^{\circ}$ $(23 \%)$. Western and northern aspects of spoil heap are predominant, where W: $24 \%$, N: $21 \%$; WN: $9 \%$; SE: 16\%; NE/E: $10 \%$ each and S/SW 5\% each.

\section{Digital Forest Map (DFM)}

Every area, which belongs to the Polish State Forest National Holding, should be covered by an DFM, to have a relation to the descriptive data base SILP (forest inventory data). On checking the geometrical correctness for Turow and Belchatow spoil heaps it was find out that many errors of the compartment borders can be find (Figure 3). This is because of the problems of the reference point on reclaimed areas and lack of GNSS precise measurement done by Forest service or the lignite mining responsible for reclamation (afforestations). The first step was, the updating of the DFM, using nDSM in the background. Although there are examples of successful automatic forest delineation based on ALS data (Eysn et al., 2014; Sačkov and Kardoš, 2014), in the presented study the DFM was updated manually.
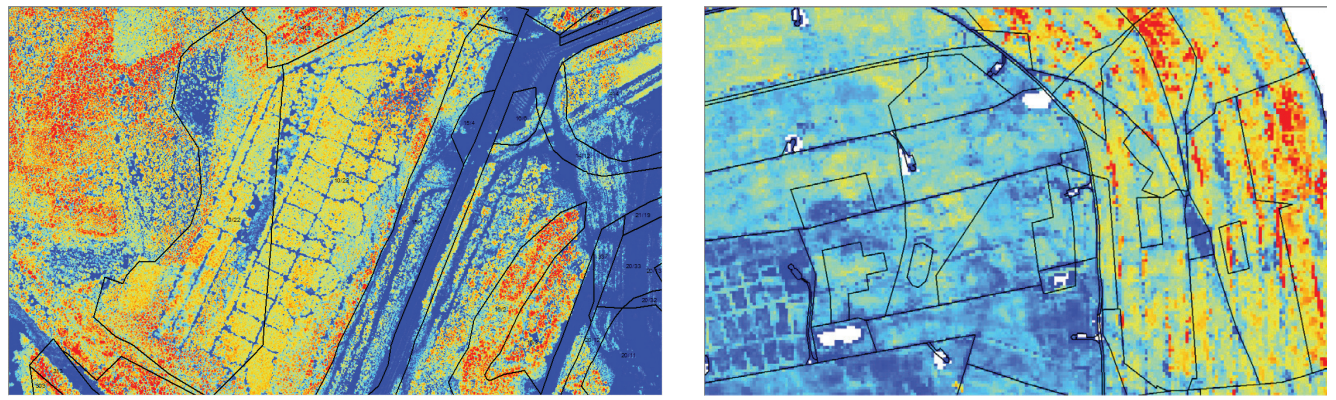

Fig. 3. Errors in geometry of Digital Forest Map (DFM) checked on nDSM (left: Turow, right: Belchatow spoil heap)

\section{The 2D and 3D Structure of High Vegetation}

One of the important characteristic obtained from ALS point cloud, which enables $3 \mathrm{D}$ analysis of vegetation, is the number of returns. For example in the analyzed sub-compartment no.: 21/2 (Turow) the number of subsequent fractions of returns shows that the area is covered by tall vegetation, because more than $35 \%$ of registered impulses makes: a second, third and forth echo. Using different software, e.g. LAStools, the 2D analysis of the distribution of subsequent returns is possible, looking for examples for places, where the signal reflects only from the ground or 
only from vegetation cover, not penetrating further (useful in leaf-ON period in case of deciduous stands).

To perform the 3D statistical analyses, the ALS point cloud is reduced to so called normalization to eliminate the influence of the changing surface of ground (Figure 4). After normalization the ground only gets $0.0 \mathrm{~m}$ and the remaining ALS points the relative height up to maximum value (e.g. $32.5 \mathrm{~m}$ ). Often the tree crowns growing over very steep slopes can get an overestimated value of the normalized height because of DTM used for this projection. The CloudMetrics software (FUSION package; McGaughey, 2012) can be used for calculating values, like minimal and maximal height, mean, median, standard deviation, skeweness of distribution or the values of subsequent percentiles. These statistics are very useful for forest application. The parameter "Percentile 95" for example describes the height, below which there are 95 per cent of the whole analyzed population of the ALS points. The results of selected 3D parameters for selected sub-compartment 21/2 (Turow) are presented below (Table 1).
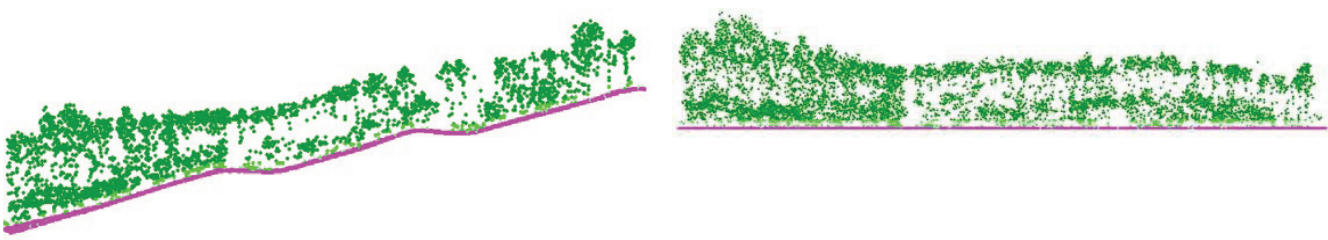

Fig. 4. Cross-sections through the classified ALS point cloud in sub-compartment 21/2 (left) and the normalized point cloud (right)

Table 1 . Basic 2D/3D indices calculated by cloudmetrics (McGaughey 2012) on ALS point cloud

\begin{tabular}{|c|c|}
\hline Statistics & Value [m] \\
\hline maximal Height & 26.64 \\
\hline mean Height & 3.70 \\
\hline Height - Standard deviation & 5.53 \\
\hline height - Variance & 30.54 \\
\hline height - Percentile 75 & 6.83 \\
\hline height - Percentile 80 & 9.56 \\
\hline height - Percentile 85 & 13.52 \\
\hline height - Percentile 95 & 15.01 \\
\hline height - Percentile 99 & 17.76 \\
\hline
\end{tabular}


The horizontal canopy density (2D) in the subcompartments established on the spoil heaps, can also be defined and visualized in a raster form (ASCII Grid) using cover algorithm (FUSION). For each pixel defined by the size, e.g. $10 \times 10 \mathrm{~m}$, a number of first echoes compared to all the registered returns inside the analyzed raster is calculated (values $0-100 \%$ ). The user depending of the undergrowth can set the heightbreak for calculating the cover of the main crow layer. Performing a traditional forest inventory is a subjective assessment of tree stand canopy density made by a person, who usually has no possibility of objectively choosing the check point characterizing the whole area. On the contrary, ALS method allows objective comparison of the results from many years of the ALS campaigns in the same range $(0-100 \%)$.

Based on normalized ALS point cloud the maps of spatial distribution of woodland height can be made to help the forest service to make a suitable decision by the forest managers concerning some silvicultural treatments or even changing the local water relations. The presented maps (Figure 5) show the in 2D the distribution of 3D information of the height of vegetation.

One possible analysis of the 3D vertical structure of forest vegetation can be retrieved using the command DensityMetrics (FUSION; McGaughey, 2012). The algorithm allows the information to be generated on a number of points e.g. in $1.0 \mathrm{~m}$ vertical intervals, for subsequent raster cells (e.g. GSD $10.0 \mathrm{~m}$ ). The single $1.0 \mathrm{~m}$ sections in the graph (Figure 6) can be analyzed to find second layer (undergrowth or the base of the crowns of the first floor).

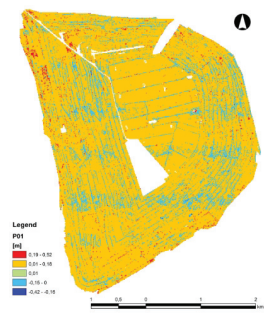

Percentile 01

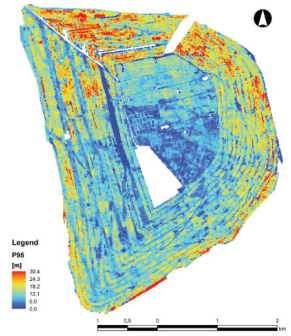

Percentile 95

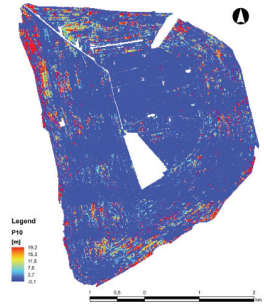

Percentile 10

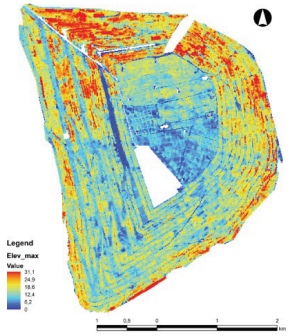

Elevation maximum

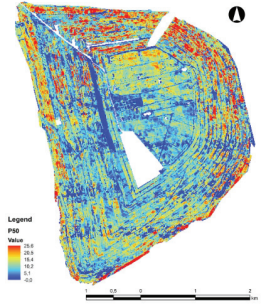

Percentile 50

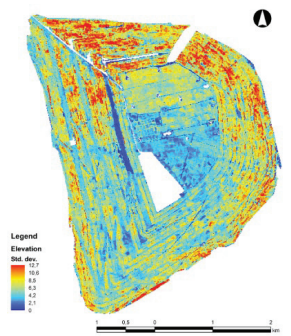

Elevation - Std. Dev.

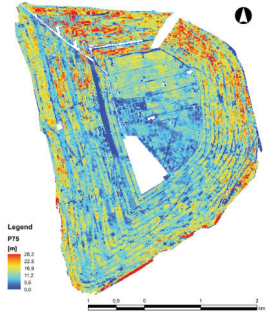

Percentile 75

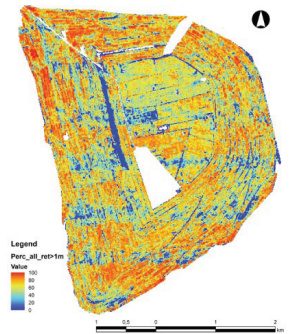

All returns $>1 \mathrm{~m}(\%)$

Fig. 5. The different metrix of the height of the forest stands or young plantations growing on the Belchatow spoil heap 


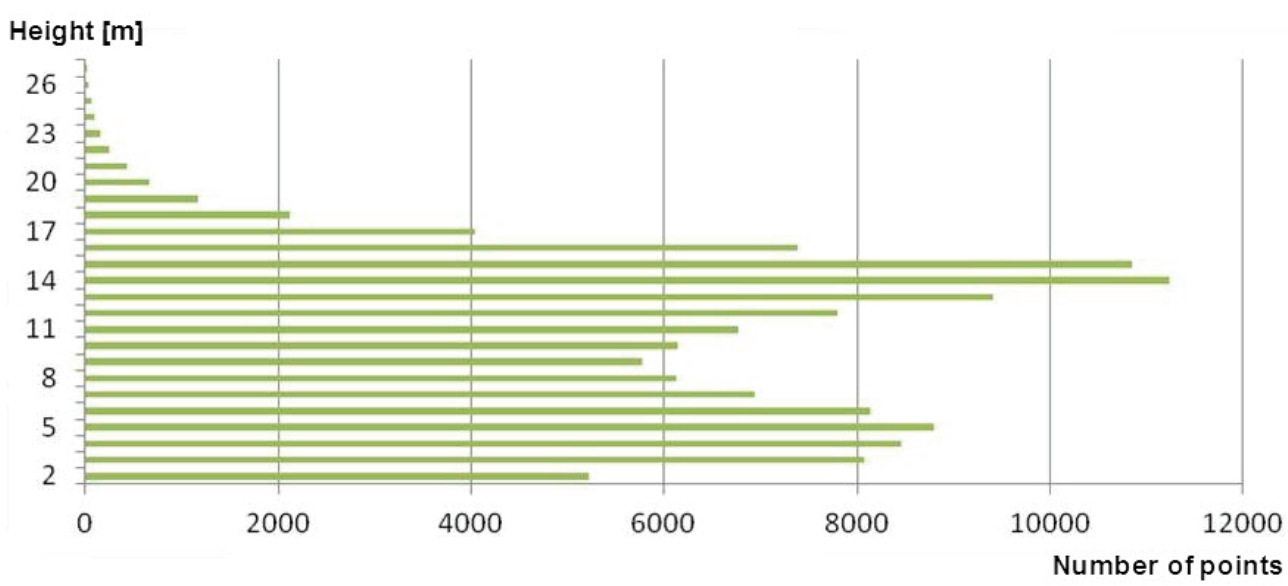

Fig. 6. The histogram of the number of ALS impulses returned from the vegetation on different heights (heightbreak $>1 \mathrm{~m}$, layers $1.0 \mathrm{~m}$ thick; GSD $10 \mathrm{~m}$ )

Analyzing the above graph (Figure 6) one can notice that the vegetation occurring in subcompartment $21 / 2$ (Turow) has relatively uniform character, because all the layers, starting from $1.01 \mathrm{~m}$ to about 16 meters are represented by a similar number of returns. From about $17.0 \mathrm{~m}$ above the ground, the number of points decreases significantly. For each forest subcompartment on the spoil heap the 3D surface of vegetation canopy can also be calculated. This can be done by GridSurfaceStats and SurfaceStats commands (FUSION). With this method, each pixel can represent using the following raster layers: maximal height, standard deviation of potential volume (based on maximal value of the height of ALS point inside the analyzed cell) and surface volume ratio (calculated as ratio $=$ surface volume/ potential volume. The Area 3D made by CHM in upper example was about $92.736 \mathrm{~m}^{2}$, while the area of the projection 2D was only $35.169 \mathrm{~m}^{2}$. The volume of the space under the approximated CHM (nDSM) surface was $281.361 \mathrm{~m}^{3}$. Of course not the whole 3D space is fully filled with green vegetation, but if proper methods are applied, it will be possible to obtain the parameters of the statistical model describing the relations between biomass derived in the field (AOI) and 3D indices calculated based on the ALS point cloud.

The vegetation characteristics of the forest stands in Belchatow established through the analysis of the ALS point cloud, is given below (Figure 7). In the presented project, the advanced spatial analysis was also implemented (3D GIS), based on the reference models derived from the ALS data (Figure 8). 

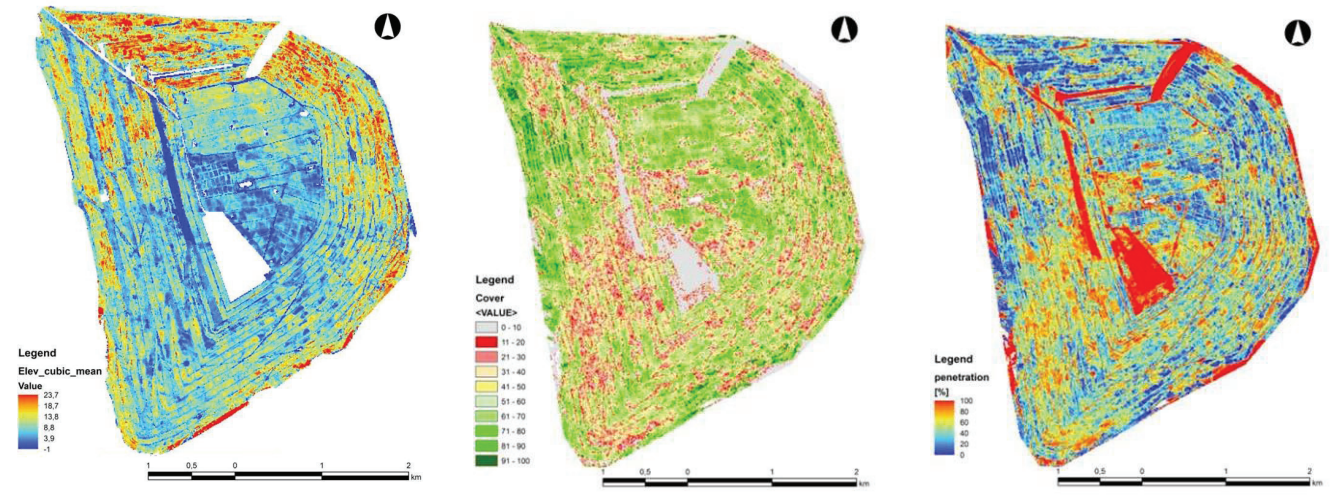

Fig. 7. The Belchatow spoil heap - 3D metrix, from left: height of vegetation, cover density and penetration
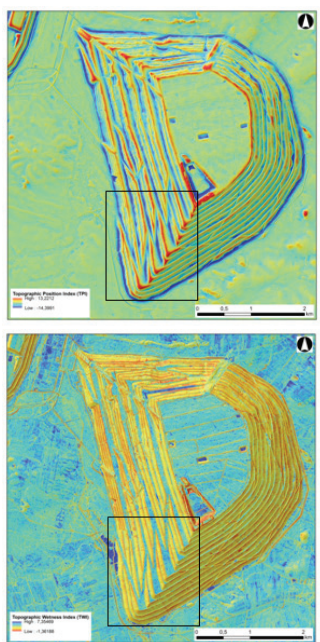
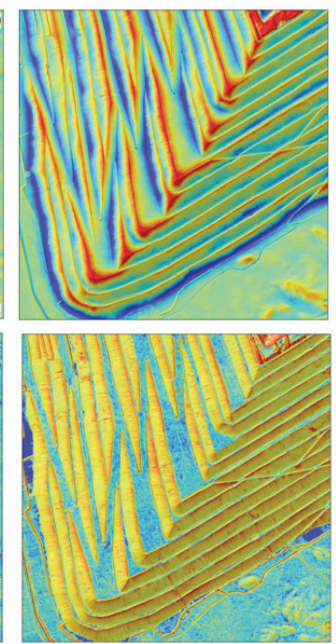
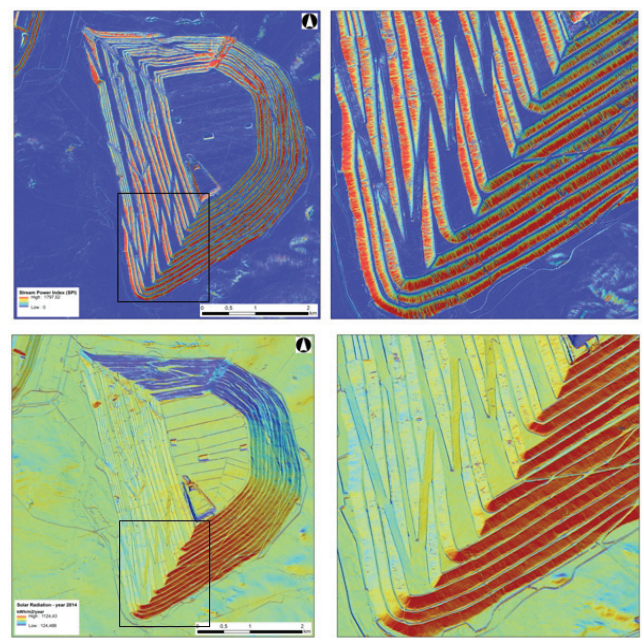

Fig. 8. The Belchatow spoil heap - 3D GIS, from top-left: Topographic Position Index (TPI), Stream Power Index (SPI), Topographic Wetness Index (TWI) and Solar Radiation

\section{Conclusions}

Application of ALS point clouds analysis in obtaining selected forest inventory parameters opens up new opportunities in mapping and monitoring large areas, especially those involving the process of automation and integration of geodata (Maltamo et al., 2014; White et al., 2013). ALS technology allows the integration of new methods, in which, in the first stage - the assessment of the forest cover state should be carried out using the spatial LiDAR indices of 2D/3D structure, first modifying the DFM's of the sub-compartment. At the second stage, after the selection 
of proper stratification groups (with support of GIS), the selection of proper AOI on derived raster maps (e.g. percentile 95; canopy, etc) must be performed and they should be found in the field (GNSS receivers) for the ground truth. Those areas (plots, transects) will provide the information, which cannot be directly obtained from ALS (like DBH, tree species; sub-species etc.). In the last stage using reference data and mathematical models we can describe, e.g. the influence of: slope, aspect, height a.s.l., soil type, the content of macro and microelements, tree species etc. on biomass production. The automatic generation of spatial $(2 \mathrm{D} / 3 \mathrm{D})$ characteristics of vegetation will allow the extension of biodiversity, biomass studies, hydrologic analyses (e.g. USLE model), or other GIS spatial analyses (like potential of solar energy), in which up-to-date and precise information on the LULC is used in different decision support systems managed such areas. Undoubtedly the integration of ALS and locally taken TLS scans for representative areas (Wezyk 2012), gives new possibilities in automatic processes of precise modeling of vegetation 2D/3D structure growing on post-mining areas. Even MLS integration is possible if a proper network of roads exists. Finally, different drones (UAV) are nowadays offering, not only ALS point cloud data, but also mutli- or hyperspectral imagery at the same time as well. Aerial photographs taken with very high overlap (e.g. $80 \%$ in leaf-ON period) can be used for generating very dense point clouds using a photogrammetry/computer vision approach - so called: stereomatching (e.g. Semi Global Matching algorithm). This low-cost solution is very competitive to airborne LiDAR but need the detailed DTM, which in turn, requires an ALS data derived in leaf-off period.

The devastated areas must be returned to nature using the reclamation investments according to the Polish laws of the environment. The ALS technology can help not only the quarrying industry building-up new $3 \mathrm{D}$ artificial objects in the landscape to check the risk of erosion and landslides or earth volumes, but can also support forest managers responsible for the wood biomass production, in areas transferred back to nature.

\section{Acknowledgments}

The article is based on own research conducted at the Faculty of Forestry, University of Agriculture in Krakow and ALS data processing performed at ProGea Consulting servers.

\section{References}

Axelsson, P. (2000). DEM generation from laser scanner data using adaptive TIN models. International Archives of Photogrammetry and Remote Sensing, Vol. XXXIII/4B, 110-117.

Drzewiecki, W., Wezyk, P., Pierzchalski, M. and Szafrańska, B. (2014). Quantitative and qualitative assessment of soil erosion risk in Malopolska (Poland), supported by an object-based analysis of high-resolution satellite images. Pure and Applied Geophysics, 171(6), 867-895. DOI: 10.1007/ s00024-013-0669-7 
Eysn, L., Hollaus, M., Schadauer, K. and Pfeifer, N. (2012). Forest Delineation Based on Airborne LIDAR Data. Remote Sensing, 4(3), 762-783.

Hejmanowska, B. (2006). The use of remote sensing in monitoring the degraded areas by mining activities, New Mining, No. 1, www.nowegornictwo.pl

Hyyppä H., Yu X., Hyyppä J., Kaartinen H., Kaasalainen S., Honkovaara E. and Ronnholm P. (2005). Factors affecting quality of DTM generation in forested areas. The International Archives of the Photogrammetry, Remote Sensing and Spatial Information Sciences, 36 (3/W), 85-90.

Koch, B., Heyder, U., Straub, Ch. and Weinacker, H. (2006). 3D Data for Forest and Environmental Planning. Int. Workshop "3D Remote Sensing in Forestry", Vienna, Austria, 1-14.

Kraus, K. and Pfeifer N. (1998). Determination of terrain models in wooded areas with airborne laser scanner data. ISPRS Journal of Photogrammetry and Remote Sensing, 53(4), 193-203.

Maltamo, M., Naesset, E. and Vauhkonen, J. (2014). Forestry Applications of Airborne Laser Scanning. Concepts and Case Studies, Springer, pp. 464

McGaughey, R. J. (2012). FUSION/LDV: Software for LiDAR data analysis and visualization. Software Manual. FUSION - version. 3.10. USDA Forest Service. Pacific Northwest Research Station.

Næsset, E. (1997). Determination of mean tree height of forest stands using airborne laser scanner data. ISPRS Journal of Photogrammetry and Remote Sensing, 52 (2), 49-56.

Pietrzykowski, M. and Krzaklewski, W. (2007). An assessment of energy efficiency in reclamation to forest. Ecological Engineering, 30, 341-8.

Rapidlasso (2014). http://rapidlasso.com. Access at 04. July 2014.

Sačkov, I. and Kardoš, M. (2014). Forest delineation based on LiDAR data and vertical accuracy of the terrain model in forest and non-forest area. Annals of Forest Research, 57(1), 119-136

Szostak M., Wezyk, P. and Tompalski, P. (2014). Aerial Orthophoto and Airborne Laser Scanning as Monitoring Tools for Land Cover Dynamics: A Case Study from the Milicz Forest District (Poland). Pure and Applied Geophysics, 171(6), 857-866, DOI: 10.1007/s00024-013-0668-8

Szostak, M. \& Wezyk, P. (2013). GNNS measurements in forest environment using various receivers and measurement modes. Archive of Photogrammetry, Photogrammetry, Cartography and Remote Sensing, 25, 217-231.

Wezyk, P. (2008). The LiDAR point cloud data-based forest canopy modelling. Archive of Photogrammetry, Photogrammetry, Cartography and Remote Sensing, 18 b, pp. 685-695.

Wezyk, P. (2012). The integration of the Terrestrial and Airborne Laser Scanning technologies in the semi-automated process of retrieving selected trees and forest stand parameters. Ambiencia, Vol. 8. 4, Unicentro, Parana, Brasil,533-548.

Wezyk, P., Borowiec, N., Szombara, S.M and Wanczyk, R. (2008). Generation of digital surface and terrain models of the Tatras mountains based on airbone laser scanning (ALS) point cloud. Archive of Photogrammetry, Photogrammetry, Cartography and Remote Sensing, 18 b, 651-661.

Wezyk, P. and Krzaklewski, W. (1999). Opportunities, problems and results of the use of digital photogrammetry techniques, GPS and GIS in land reclamation sand mine. Conference: Opencast mining - Environment - Reclamation - with particular regard to KWB Belchatow, Belchatow, 8-9. 06.1999, 147-154.

Wezyk, P., Szostak, M. and Tompalski, P. (2013). Use of Airborne Laser Scanning Data for a Revision and Update of a Digital Forest Map and its Descriptive Database: A Case Study from the Tatra National Park. The Carpathians: Integrating Nature and Society Towards Sustainability, Part IV (pp. 615-627). Springer Berlin Heidelberg, DOI: 10.1007/978-3-642-12725-0_43

Wezyk, P., Tompalski, P., de Kok, R., Szostak, M. and Kukawski, M. (2010). Method of the tree number estimation in the pine stand using ALS data and true orthoimages. Sylwan, 154 (11), 773-782.

White, J.C., Wulder, M.A., Varhola, A., Vastaranta, M., Coops, N.C., Cook, B.D., Pitt, D. and Woods, M. (2013). A best practices guide for generating forest inventory attributes from airborne laser scanning data using the area-based approach. Information Report FI-X-10. Natural Resources Canada, Canadian Forest Service, Canadian Wood Fibre Centre, Pacific Forestry Centre, Victoria, BC. pp. 50 
Witkowski, J. and Dmochowska, H. (2013). Statistical Yearbook of the Republic of Poland 2012. Warszawa: Central Statistical Office.

Wójcik, J. and Krzaklewski, W. (2009). Forestation as the Method of the Remediation of Soilless Areas of the Lignite Mine Turow. Gospodarka Surowcami Mineralnymi, 25(3), 171-187.

Yu, X., Hyyppä, J., Kaartinen, H. \& Maltamo, M. (2004). Automatic detection of harvested trees and determination of forest growth using airborne laser scanning. Remote Sensing of Environment, 90, $451-462$.

\title{
Monitorowanie terenów rekultywowanych z wykorzystaniem technologii LiDAR i GIS
}

\author{
Piotr Wężyk ${ }^{1}$, Marta Szostak ${ }^{1}$, Wojciech Krzaklewski², Marek Pająk ${ }^{2}$, \\ Marcin Pierzchalski $^{3}$, Piotr Szwed ${ }^{3}$, Pawel Hawryło ${ }^{1}$, Michał Ratajczak ${ }^{1}$ \\ ${ }^{1}$ Uniwersytet Rolniczy w Krakowie, Wydział Leśny \\ Instytut Zarządzania Zasobami Leśnymi \\ Zakład Urządzania Lasu, Geomatyki i Ekonomiki Leśnictwa - Laboratorium Geomatyki \\ Aleja 29 Listopada 46, 31-425 Kraków \\ e-mail: p.wezyk@ur.krakow.pl; m.szostak@ur.krakow.pl; p.hawrylo@ur.krakow.pl; gorhydrus@gmail.com \\ ${ }^{2}$ Uniwersytet Rolniczy w Krakowie Wydział Leśny \\ Instytut Ekologii i Hodowli Lasu, Zakład Ekologii Lasu i Rekultywacji \\ Aleja 29 Listopada 46, 31-425 Kraków \\ e-mail: wkrzak@ar.krakow.pl; rlpajak@cyf-kr.edu.pl \\ ${ }^{3}$ ProGea Consulting Kraków \\ ul. Henryka Pachońskiego 9, 31-223 Kraków, Poland \\ e-mail: marcin.pierzchalski@progea.pl; piotr.szwed@progea.pl
}

\section{Streszczenie}

W wyniku działalności wydobywczej, w tym eksploatacji odkrywkowej, krajobraz naturalny zostaje całkowicie zmieniony, powstają wielkoobszarowe tereny bezglebowe w formie zwałowisk i wyrobisk. W celu powstrzymania degradacji środowiska oraz odtworzenia warunków przyrodniczych konieczne staje się objęcie tych terenów rekultywacją i zalesianiem, z uwzględnieniem różnych warunków wzrostu roślinności, wynikających z ukształtowania terenu (nachylenie, ekspozycja, kierunek wiatru i opadów, dopływ energii słonecznej, itp.) czy rodzaju gruntu. Technologia lotniczego skanowania laserowego (ALS) dostarcza chmury punktów (XYZ) oraz ich pochodne w postaci rastrowych modeli wysokości, które umożliwiają wyznaczenie wybranych parametrów 2D i 3D roślinności (np. wysokość drzewostanów i pojedynczych drzew, wysokość podstawy korony, zwarcie, biomasa, itp). Automatyzacja przetwarzania chmur punktów ALS i integracja wyników w systemach GIS pomaga w podejmowaniu decyzji, dotyczących zabiegów hodowlanych, także na obszarach szczególnie trudnych dla adaptacji roślinności (toksyczne gleby, susze na południowych stokach, obsunięcia ziemi). Ogólnokrajowy projekt ISOK jest źródłem danych pochodzących ze skanowania laserowego, które z powodzeniem mogą być używane do monitorowania i zarządzania wieloma tysiącami hektarów zniszczonych terenów poprzemysłowych, które zgodnie z prawem mają zostać zalesione i przekazane pod działanie Lasów Państwowych. 